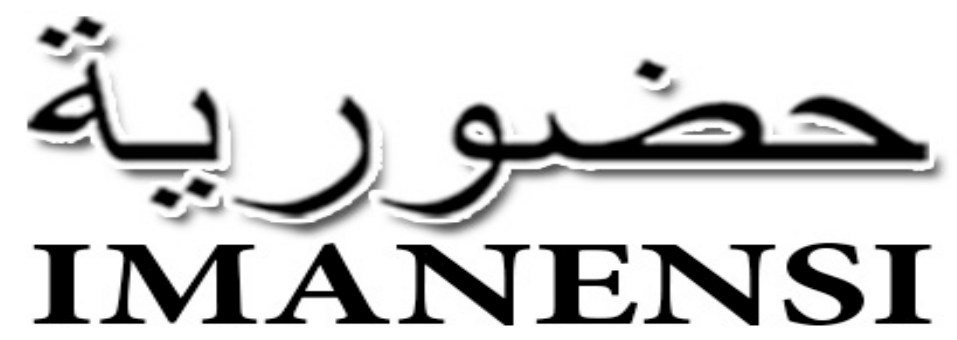

(Jurnal Ekonomi, Manajemen, dan Akuntansi Islam)

Vol 4, No 1, Maret 2019, Hlmn. 14-22

\title{
Towards the concept of divine justice income: an imaginary dialogue
}

\author{
Rosyid Arifin, Ayudia Sokarina \\ a Universitas Wisnuwardhana, J1. Danau Sentani Raya No.99 \\ Malang, Jawa Timur, Indonesia 65139 \\ b Universitas Mataram, J1. Majapahit No.62 Mataram, NTB \\ Indonesia 83115 \\ 1* ayudia.sokarina@gmail.com \\ doi: 10.34202/imanensi.4.1.2019.14-22
}

\begin{abstract}
Abstrak
Tulisan ini adalah sebuah dialog imajiner antara dua akuntan yang berbeda latar belakang lingkungan pendidikan. Salah seorang dengan pendidikan sekuler (akuntan-sekuler: Asek) dan seorang lainnya berasal dari lingkungan pendidikan pesantren (akuntan-syariah: Asyah). Keduanya berdialog mengenai konsep income hingga melahirkan sebuah konsep yang mereka sebut sebagai konsep income berkeadilan Ilahi. Konsep income berkeadilan Ilahi mengandung tiga rukun yaitu: rukun paritas, rukun kewargaan, dan rukun pembuktian. Ketiga rukun itu digambarkan seperti struktur lapisan bumi. Tulisan ini menggunakan dialog imajiner sebagai sebuah metode yang dikategorikan dalam paradigma postmodern. Ini adalah sebuah cara unik untuk memberikan pencerahan bagi perkembangan akuntansi syariah.
\end{abstract}

Kata Kunci: akuntansi syariah; keadilan ilahi; dialog imajiner; pendapatan; dan pesantren.

\begin{abstract}
This paper is an imaginary dialogue between two accountants who have different educational background environments. The first accountant is from secular education environment (secular accountant: Asek) and the second accountant comes from pesantren education environment (sharia accountant: Asyah). Both of them discuss about the concept of income to initiate a concept which is called Divine Justice Income. The concept of Divine Justice Income consists of three pillars, namely: parity pillar (rukun paritas), kinship pillar (rukun kewargaan), and social welfare pillar (rukun pembuktian). All pillars are illustrated just like the layer of earth. This paper employs an imaginary dialogue as the method which is categorized as postmodern paradigm. This is a unique way to provide insight for the development of sharia accounting.
\end{abstract}

Keywords: sharia accounting; divine justice; imaginary dialogue; income; and pesantren.

This is an open access article under the CC-BY-SA license.

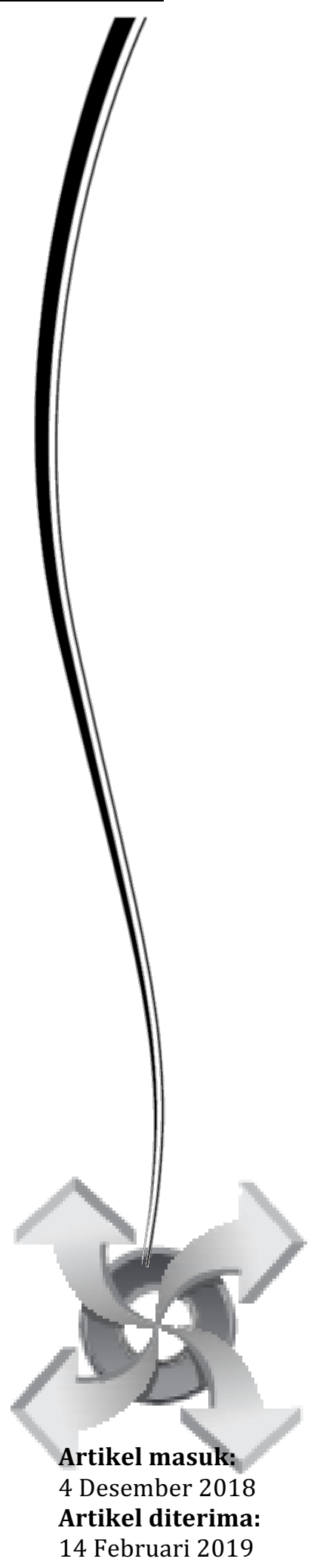




\section{Prolog: Secular Accountant (Asek) and Sharia Accountant (Asyah) Discussing About the Concept of Income}

One fine day, two accountants walk along the white sand beach. They are captivated by the view of lofty seaside hotels which stand tens of meters. Then, they start a conversation:

Asek: "My dear friend Asyah, what do you see? Don't you think that the sea is more interesting than that crowd?" (Almost all the hotels offers beachfront facilities for the guest to enjoy the sun)

Asyah: "Can you tell me what I can see?"

Asek: "Whew... There are many things that you can see, the white sand, those big walls around the hotels, swimming pool, even the people passing by."

Asyah: "If we think about an organization, which one is the organization?"

Asek: (raise his eyebrows) "Um, it must be all the things that I've mentioned."

Asyah: "Exactly, it means that the beach, sea, and rocky hills around the hotels are considered as an organization."

Asek: "Well actually I don't think that far by considering beach, sea, and rocky hills as an organization, what an enlightenment for me today. But what if an organization is sold?"

Asyah: "I can answer your question based on Hines's opinion (Hines, 1988), his statement comes up after the sale happened. The definition of sale depends on different concept. It means that everyone can create a concept. Thus idea, theory or concept are created and formed in order to build a reality. It can be changed as the time passing by. For example, the concept of sales will be created based on changing discretion, but repeated experience-based in the form of policy is needed to make it right. Later on, it will be a truth. If a reality is created and formed, there will be some consequences that must be obeyed. For example, the factory waste will not be considered in a financial report before it has an impact on something. Thus the factory waste needs to be included in the report. In other words when the waste increases the expense, the company will always count it as profit deduction. The more products the company produces, the more its waste is. Shortly, the picture of reality will never be perfect because each person can only picture it a half. A reality is created and formed, thus it depends on the people's deepest strength to communicate the reality in order to develop a trusted reality for others."

Asek: "Perfect, you open up my mind. Thanks mate."

Asyah: "Furthermore, the concept of income will never be perfect too. It can be seen from the interpretation result of the nature of income which is getting worse (Riahi \& Belkaoui 2006: 279). In general, income from the comprehensive point of view acknowledges all of the revenues from business and investment activities. This is consistent with the definition used by the Accounting Terminology Bulletin No. 2, which mentions that :

An income is generated from the sale of goods and delivery of services, and it is also measured with the encumbrances to the customers, clients, or tenant for goods and services provided for them. An income also includes the profit from the sales or assists exchange (other than traded shares), interest and dividends earned from investments, and other increases in the owner equity except from the capital contributions and capital adjustments.

A narrow vision will only include the results from activities which provide income, and expend investment profit as well as profit and loss from the fixed assets. Based on this view, American Accounting Association states the definition of net profit as follows:

... the excess of income deficiency compares to the expired cost as well as profit and loss for a company as the result of sales, exchanges, or other assets conversions." 
In order to acquire the concept of income, this paper presents imaginary dialogue between Asek, a junior accountant from secular education background, and Asyah, a senior accountant from pesantren ${ }^{1}$ education background. However, both of them are at the same age and they also have considerable concern for accounting discipline.

Going Through the Wall of Profit Concept. The concept of profit always be the main concern of economics experts including the figure of classical economic, Adam Smith. He defines profit as an increase in wealth (Riahi \& Belkaoui 2007: 232). After that, most of the believers of this concept agree with his thought. Thus it affects the conceptualization of the business practices. Entering the $20^{\text {th }}$ century, the thought about profit continues to develop. It can be seen from the definition of profit which is proposed by Fisher, Lindahl and Hicks.

Fisher divides a profit based on the owners preferences, it covers psychological profit, real profit and money profit. Psychological profit is defined as the psychological enjoyment of goods and services from personal consumption. Real profit is a profit that can be measured by the cost of living. Money profit is the amount of money which is received and consumed to pay the cost of living. Furthermore, Lindhal develops the concept of profit as an interest, interest is a the appreciation for capital goods during the period. Then, Hicks defines economic profit as the maximum amount of consumption in a week to provide one week needs. In this case, Hicks has a concern for the adequacy which has been ignored in the definition given by Fisher and Lindahl.

Regarding to the emergence of profit which has been inherited the genetic factors of enjoyment, the use of profit in business activities is getting out of control. It is summarized in the explanation by Lehman (Lehman, 2006) as follows: a) Profit and loss statement is a report which summarized a company's achievement in a certain period; b) In recent years, profit had dominated the financial discussion to assess and compare a company's performance; c) Net profit indicates the achievement of a company's operating activities during a certain period; d) Profit and loss statement helps the reader to evaluate a company's performance during a certain period and make a performance projection for the future; e)The net profit flow from operating activities and net profit pictures the operating activities performance of a company in a certain period; f) Profit is an important indicator of a company.

The domination of profit ideas becomes the great anxiety among sharia accountants, it can be seen from this following dialogue:

Asek: "Asyah, what makes you worry about profit? Look, profit can boost the tremendous spirit of an individual or organization to be successful."

Asyah: " Dear friend, listen to my poetry first.

\section{The Power of Profit}

Who are you?

As a return, you are beyond the normal yet your risks are above the average

Risk-Bearing Theory of Profit says that

You are the result of long term friction balance

Frictional Theory of Profit says that

You are the result of cartel which limits the output

Monopoly Theory of Profit says that

You are the return of innovation success

Innovation Theory of Profit says that

You are the result of efficiency management

Managerial Efficiency Theory of Profit says that

All theories agree if you are the fetus of a powerful womb

You were born to rule the world

1 Pesantren is the Islamic private educational institution which has characteristics indepently, allowing more flexibility to rely on innovation in order to realize the relevance of education that in line with the development of science and technology. 
You sneak in the synapses of the capital owners

You grow your selfishness

You refine the materialism

You spread the hedonism

Oh, your power nearly has no boundary

Yes, you are the profit

The profit of earth scrapers

The profit of illegal loggers

The profit of forest firebugs

The profits of state-owned enterprises traders

The profit of the powerful one

Moreover

The profit of God disbelievers

Oh what a powerful you are, the profit."

Asek: "You look disappointed with the profit acknowledged by many accountants today. So, sanctify that inhuman profit. But, what will you do? Can you?"

Asyah: "Of course I can, I will think and fight in the battle of acquiring knowledge (Nataatmadja, 2010). My dear friend Asek, will join me to make a concept of income based on the six articles of faith? "

\section{Grasping the Value of Divine Justice}

Asyah: "Actually, injustice is the root of the problems that always occurs due to distribution failure of profits and the most important thing is the loss of the divine value in the profit itself. This is proven by several studies (Andrianto \& Irianto, 2008; Irianto, 2006; Noch, 2013; Sokarina, 2011). The principle of justice is based on the concept of income distribution according to classical economics, it is the result of the surplus variability or uncertainty of structural production. Surplus can significantly rise if the wage is zero, and vice versa (Caporaso \& Levine 2008: 117). I believe that there will some people who are sacrificed in order to give justice for others. I identify that matter as illusive justice, no wonder that the social prosperity is just an illusion too. Basically, people need parity or partners as their manifestation of the life balance in this world. The parity of material world is the spiritual word which becomes the moral background. The highest moral background for Moslem is Al-Qur'an. It is stated in surah Al-Imran: 3 (Kementerian Agama, 2011):

It is He Who has sent down the Book (the Qur'an) to you (Muhammad) with truth, confirming what came before it. And he sent down the Taurat (Torah) and the Injeel (Gospel) (Qs. Al-Imran: 3).

Al-Qur'an presents a thorough ecological model of social welfare for ummah. It covers social issues such as poverty alleviation, justice distribution, participations and rights empowerment through cooperative, etc. (Choudhury 2008: 255). In order to achieve social welfare, a justice must be based on AlQur'an. Divine justice ${ }^{2}$ is a kind of justice which exceeds material justice. Divine justice along with affection (ihsan), balance (mizan), human solidarity (ikhwa), moderation (la israf), tolerance, cooperation and awareness (tadabbur dan tafakkhur) are the manifestation of Islamic law which are obtained from all of the creatures intrinsic worship experiences (tasbih) (Choudhury 2008: 245)."

Asek: "What a wonderful Islam. Besides, the experts of Islam economic had identified the unique institutional rules of system. It based on Siddiqi's explanation (Siddiqi 1989: 254-255), he mentions that:

1. Interest is from the profit distribution.

2 Divine justice is the free definition of Al'adl wa'l Ihsan from a researcher. According to quoted by Asutay[16] Al'adl wa'l Ihsan is defined as the individuals who are expected to establish justice ('adl) and proclaim for charity (ihsan) in order to achieve social welfare. 
2. The money making from an investment process is compared to a saving and loan process.

3. Social institution, especially state-owned institution, plays an active role in the economic process to convince the realization of social purposes.

4. Providing alms service as an effective instrument to transfer some resources from the rich to the poor in order to give social purpose contribution.

5. The level of minimum income is guaranteed for all people but they are expected to work according to their abilities.

The characteristics of Moslem are based on some sources such as: (1) visualization of Al-Quran and Hadist, (2) The history of Islam during authentic period, first 40 years."

Asyah: "We cannot deny that Islam is suitable to be applied even to the micro economic. It is also suitable to design the concept of income based on the nature of Islam both for individual or people in general."

Methodology: One Way to Divine Justice Through Hidayat Nataatmadja Thought

Asyah: "In order to internalize the value of divine, I use the idea from Natatmadja (Nataatmadja, 2010). Nataatmadja's thought (Nataatmadja, 2010) is used because it is based on Al-Qur'an as the source of knowledge. According to Goessom (Goessoum 2011: 83) based on Al-Qur'an, there are three sources of human knowledge, namely: (1) senses that allows humans to make observations and measurements; (2) the intelligence that allows people the ability to contemplate, reflect the reasons and others; (3) the divine revelations which directly reveal the unknown knowledge to people or help the mind to attain truth by giving allegories, intuition, sudden enlightenment, etc. Then, Nataatmadja tries to create a human model who holds Al-Quran principles just like stated in surah At-Tin : 4-6 (Kementerian Agama, 2011)!

We have certainly created man in the best of stature; then We return him to the lowest of the low, except for those who believe and do righteous deeds, for they will have a reward uninterrupted. (95: 4-6)

The best version of human is those who are godly. To be the godly human, we can acquire knowledge based on three pillars which are the operationalization of The Six Articles of Islamic Faith. Those three pillars are parity, kinship, and welfare pillar. Parity welfare is the spiritual form which becomes the pair of material forms. The rationale is based on surah An-Nisa (Kementerian Agama, 2011): 1 as follows:

O mankind, fear your Lord, who created you from one soul and created from it its mate and dispersed from both of them many men and women. And fear Allah, through whom you ask one another, and the wombs. Indeed Allah is ever, over you, an Observer. (4: 1).

This parity pillar is not recognized in the modern world because nowadays the world develops dualism pillar. It means that material is the opposite of immaterial (spiritual). This pillar is supported by kinship pillar by developing the principle of the uniqueness of being and the principle of hierarchical systems. This kinship pillar is based on surah Al-Imran, in Arabic which it means the family of Imran. The third surah in Al-Quran explains about the creation of universe by God at the same time so that there is a mutual role among His creations with one another. It is a suitable manifestation of a good family. The last pillar is welfare pillar. It is based on surah Al-Maidah, in Arabic it means the table spread with food.

... this day I have perfected for you your religion and completed My favor upon you and have approved for you Islam as religion. But whoever is forced by severe hunger with no inclination to sin - then indeed, Allah is Forgiving and Merciful. (5:3) (Kementerian Agama, 2011).

It means that the food is an empirical evidence of divine contentment, as the last verse of Quran which relates to the perfection of Islam. This is an indication that the perfection of human knowledge about the teaching of Islam will give the meaningful food. That is what we call social welfare." 
IMANENSI (Jurnal Ekonomi, Manajemen, dan Akuntansi Islam)

Vol 4, No 1, Maret 2019, Hlmn. 14-22

The methodology based on Nataatmadja's thought can be seen in figure 1 .

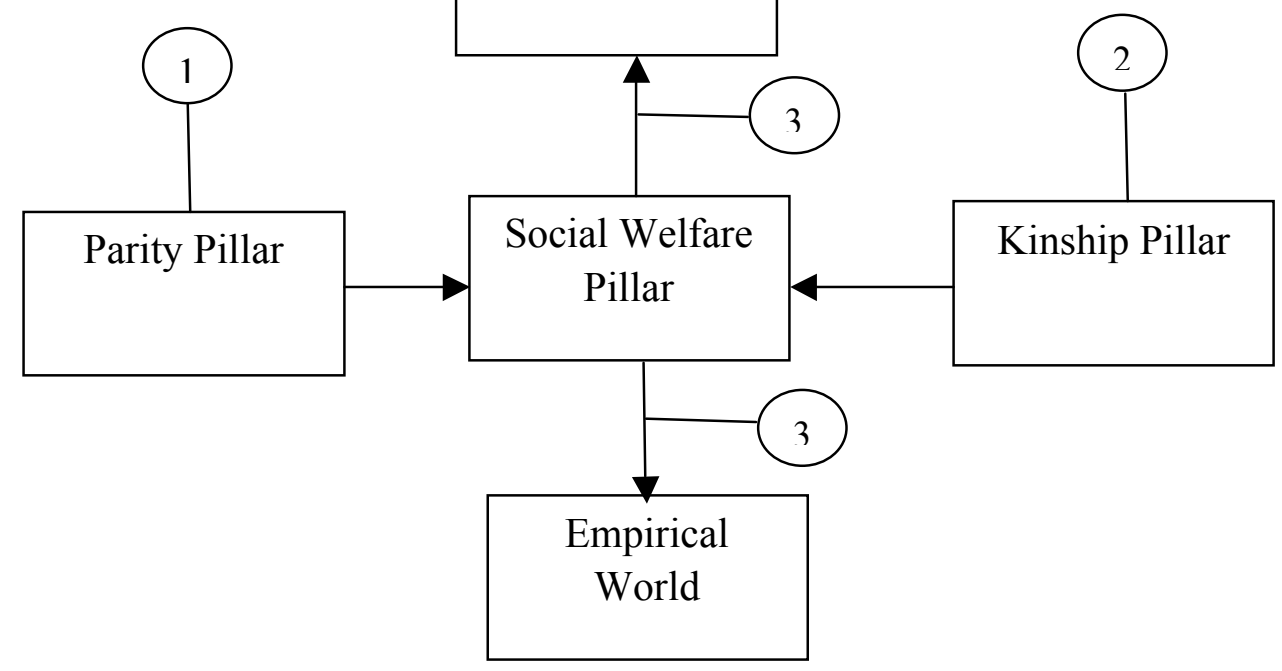

Figure 1. Nataatmadja Thought

\section{Notes:}

The first and second pillar are joined in welfare pillar as the third pillar which proves empirical and spiritual world. An empirical world is performed in a multinational company and spiritual world is the process of faith in order to achieve the divine justice proposed in this paper.

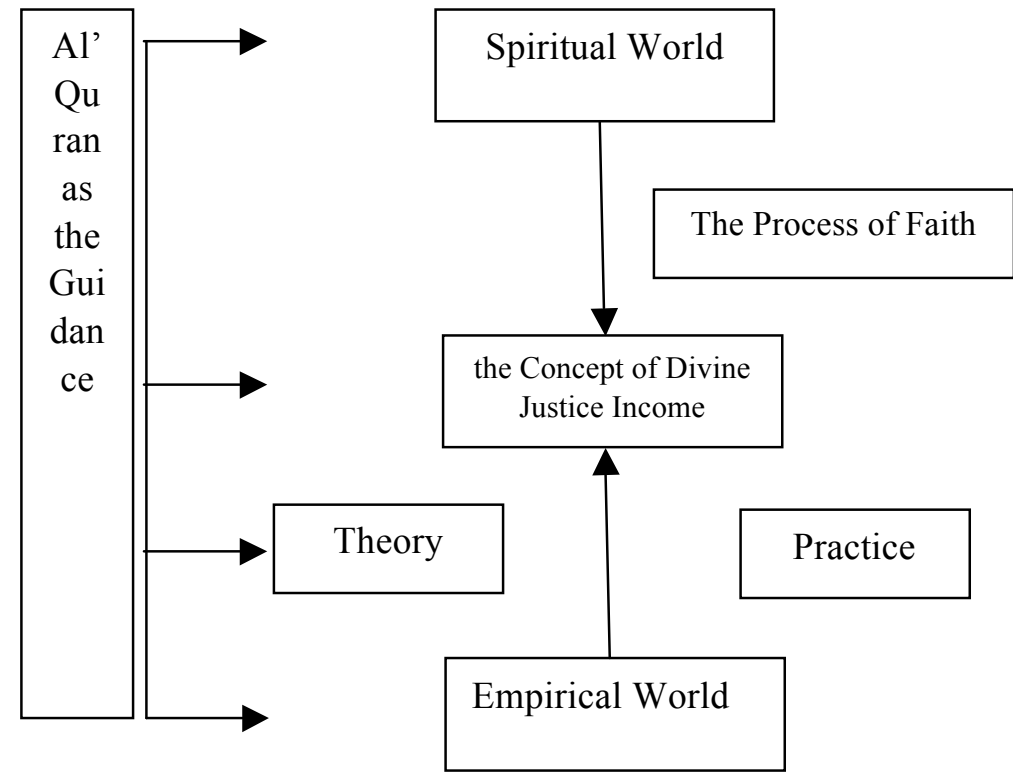

Figure 2. Analysis Technique of the Concept of Divine Justice Income 
The Concept of Divine Justice Income: The Layers Structure of Three Pillars

Asek: "Ok Asyah, now tell me about the concept of divine justice income. I cannot wait to hear that."

Asyah: "Obviously, it is based on a Nataatmadja's methodology which is based on AlQuran (see the figure 2 of analysis technique of the concept of divine justice income

The concept of divine justice income must cover three pillars namely: parity, welfare, and kinship pillar. I imagine three pillars just like the earth layers which consist of core (the deepest part), mantel (the middle layer), and crust (the outermost layer) (see Figure 3 the earth layers below) ${ }^{3}$.

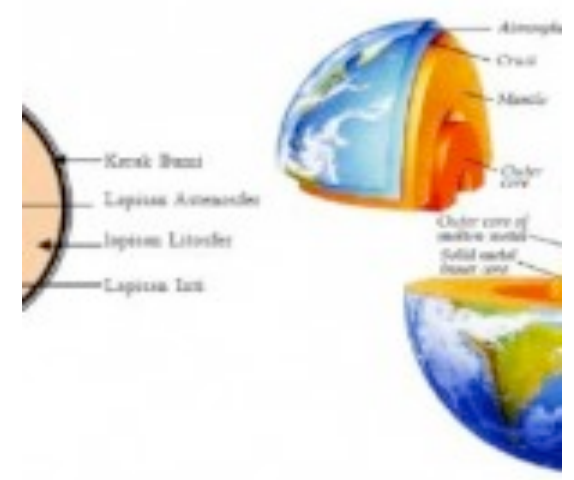

Figure 3. Earth Layers

Therefore, the concept of divine justice income can be pictured in Figure 4.



Figure 4. The Concept of Divine Justice Income

${ }^{3}$ Taken from: http://rajinbelajar.net/struktur-lapisan-bumi\#.U7VPhkAZ9Hk 
The Core - Parity Pillar In parity pillar which becomes the core of the concept of divine justice, the pairs can be seen in below:

\begin{tabular}{|c|c|c|c|c|}
\hline Objective & Sharia & Brain & Material & Khalifatullah \\
\hline$\overline{\text { Subjective }}$ & $\overline{\text { Reality }}$ & $\overline{\text { Heart }}$ & $\overline{\text { Spiritual }}$ & $\begin{array}{l}\text { Servant } \\
\text { Allah }\end{array}$ \\
\hline
\end{tabular}

$\frac{\text { Relative }}{\text { Absolute }} \quad \frac{\text { Doubt }}{\text { Belief }} \quad \frac{\text { Rationale }}{\text { Intuitive }} \quad$ Etc.

Those pairs are in the different dimension, however they unite as a pair of rights and as an inseparable synthesis. The truth will emerge if those pairs appear in a synthesis including in the concept of income. The concept of divine justice adopts parity pillar so that it can be a source in the spirit of the concept of income.

The Mantel - Kinship Pillar

Selfhood in term of quantum mechanics is actually built based on citizenship basis. Selfhood system consists of stratified hierarchy. For objects of the earth, the earth is an independent selfhood system but it has not related to the sun system; the sun system relates to the galaxy system. The concept of divine justice income is an independent system but it still relates to financial statement; a financial statement relates to accounting system.

The Crust - Welfare Pillar

Welfare pillar is the final result, so it is likened as a dish from the strong combination between parity and kinship pillar. Basically, the welfare pillar proves something through empirical and the spiritual world in order to generate the true concept of income.

\section{Epilogue}

Asek: ". My dear friend Asyah, I feel so relieved. Our anxiety about the concept of income has been answered by the concept of divine justice. I just can't wait any longer to gather empirical and non empirical proofs about this concept. Oh, here is my poetry for you.

\section{The Mask of Illusive Justice}

You produce efficiently

to achieve a sensational surplus

then you distribute it.

You promise us a market with full of imagination

You give us the auto regulation as a sugarplum

You control the private importance

But, you forget

that someone has an ambition

that someone has an obsession

that someone lives with full of politicization 
Then,

One thing that you name it as a justice

is just a mask for the justice.

Cause the justice that you distribute

is an inequitable justice.

Remove your illusive mask!

Let's assemble scientific technology

Politic,

Economy,

even Accounting

by using the value of divine.

For the real welfare

(in a repentance science)

Asyah: "That's it, this is a simple concept that allows us to fight in studying."

Asek:" Thank you so much my dear friend for this unforgettable dialogue."

\section{REFERENCES}

Andrianto, J., \& Irianto, G. (2008). Akuntansi dan Kekuasaan: [dalam konteks] Bank BUMN Indonesia (pp. iii-208). Malang: Aditya Media Publishing.

Caporaso, A. J., \& Levine, P. D. (2008). Theories of Political Economy. Cambridge: Cambridge University Press.

Choudhury, M. A. (2008). Islam versus liberalism: contrasting epistemological inquiries. International Journal of Social Economics, 35(4), 239-268. doi:10.1108/03068290810854538

Goessoum, N. (2011). Islam's Quantum: Reconciling Muslim Tradition and Modern Science. London: IB Tauris.

Hines, R. D. (1988). Financial Accounting: in Communicating Reality, We Construct Reality. Accounting, Organizations and Society, 13(3), 251-261.

Irianto, G. (2006). Dilema "Laba" dan Rerangka Teori Political Economy of Accounting (PEA). TEMA, 7(2), 141-53.

Kementerian Agama, R. (2011). Syamil Al-quran Miracle The Reference. (D. penerjemah Alqur'an, Ed.). Jakarta: PT Syamil Cipta Media.

Lehman, C. R. (2006). The bottom line. Critical Perspectives on Accounting, 17, 305322. doi:10.1016/j.cpa.2003.05.005

Nataatmadja, H. (2010). Ilmu dan Pengetahuan dalam Krisis dan Kritik: Kumpulan Karangan Terpilih 1974-1997 (Pertama). Yogyakarta: Pusat Kajian dan Dokumentasi Karya Hidayat Nataatmaja.

Noch, Y. M. (2013). Analisis Political Economy of Accounting atas Dana Otonomi Khusus Provinsi Papua. Universitas Brawijaya.

Riahi, A., \& Belkaoui. (2006). Accounting Theory (5th ed.). Jakarta: Penerbit Salemba Empat.

Riahi, A., \& Belkaoui. (2007). Accounting Theory Buku Dua. Jakarta: Penerbit Salemba Empat.

Siddiqi, M. N. (1989). Toward Islamization of Disciplines. Kuala Lumpur: International Institute of Islamic Thought.

Sokarina, A. (2011). Menggagas Dimensi Kinerja Perusahaan Berdasarkan Perspektif Political Economy Of Accounting (PEA). In Proceeding Simposium Nasional Akuntansi XIV Aceh. 